\title{
TAX POLICY AND FOREIGN INVESTMENT
}

\author{
Dan Throop SMITH*
}

No general statement concerning the effects of tax factors on transatlantic investments is accurate beyond the obvious one that taxation is always relevant. But tax considerations are seldom dominant, and differences in taxation are frequently negligible from a pecuniary standpoint, though the prospect of having to meet the reporting requirements of two or more national tax jurisdictions may deter foreign investment by small businesses. Investment climates and exchange controls generally are more important than tax differences in investment decisions. ${ }^{1}$

The net effects of taxation on any specific investment depend on the interplay of the laws of the two countries involved, the source country in which the income is earned and the destination country to which it goes. An analysis of the influence of taxation must take account of the distinctive features of each country's tax laws as they apply to income paid from it to foreign recipients and received in it from sources abroad. Principal attention in this paper will be given to the U.S. tax laws, with particular emphasis on the taxation of income received here from abroad. Comparisons with the tax laws of other countries will give perspective and will illustrate the need for precise analysis for specific investments.

The United States taxes its individual citizens and corporations currently on all income from foreign sources but allows a credit against the U.S. tax for taxes paid where the income is earned. ${ }^{2}$ These two provisions, general inclusion of foreignsource income in the U.S. tax base and general allowance of foreign taxes as a credit against the U.S. tax, are basic and long-standing in our tax law.

The only exception to these general rules as applied to individual citizens is an exemption of a limited amount of income earned abroad while resident or traveling in foreign countries. ${ }^{3}$ All investment income and all capital gains are currently taxable regardless of their sources or the place of residence of the taxpayer. Current taxability on a global basis is truly an annual price of citizenship.

* Professor of Finance emeritus, Harvard Graduate School of Business Administration; Lecturer, Stanford Graduate School of Business; Chairman, Fisons Corporation; former Deputy to the Secretary of the Treasury in charge of tax policy (during the Eisenhower Administration). Author, Federal Tax Reform (I963), TAX Factors in Business Decisions (1969).

${ }^{1}$ In fact, in both this country and France, some leading industrialists have said that they make international investment decisions on the basis of before-tax income. They justify this surprising position on the grounds that tax laws change so rapidly that a calculation of after-tax income would give a false sense of precision and, more importantly, that, if the investment climate in a country is good cnough to justify investment, it is probable that the tax burden in it, whatever form it takes, will not be far out of line with that in other countries.

${ }^{2}$ INT. REv. CODE of I954, $\$ 6 \mathrm{r}, 90 \mathrm{I}-04$. A tax credit permits a dollar-for-dollar offset against the U.S. tax; it must be distinguished from a deduction from income in computing taxable income, which leads to a net saving in tax equal to the deduction times the applicable tax rate.

${ }^{3}$ INT. Rev. CODE of r954, $\$ 9 I 1$. 
A U.S. corporation is also taxed currently on its world-wide income, regardless of the location of its offices or activities. But if it operates abroad through subsidiaries incorporated abroad, taxation generally applies only as the income is received from subsidiaries as dividends, interest, service charges, or in any other form. Consolidated financial statements, which would permit losses of foreign subsidiaries to be offset against domestic income of the parent corpoartion here or elsewhere, are not permitted. ${ }^{4}$ The principal exception to this general rule regarding foreign subsidiaries applies to the income of foreign corporations which are deemed to be used as tax havens according to objective statutory standards. The income of these subsidiaries is imputed to and taxed currently to their U.S. parent corporations.

Our system of taxation of foreign-source income means that a tax rate at least as high as the U.S. rate ultimately will be applied either here or abroad on foreign income earned by U.S. citizens and U.S. corporations. If the foreign tax, where the income is earned, is lower than the U.S. tax, the United States collects the difference; if the foreign tax is equal to or higher than the U.S. tax, there is no U.S. tax. If the foreign tax is higher than that which would be imposed in the United States, the tax burden on income from foreign investment is greater by that amount than the U.S. tax would be on domestic investment, but it is the foreign government, not the U.S. government, which is to blame. (And so long as the foreign tax is not discriminatory against U.S. corporations or their subsidiaries, the foreign tax, though high by U.S. standards, is neutral in its treatment of U.S.-owned and domestic business in the foreign country.)

In brief, the underlying objective of the U.S. income tax law is to maintain neutrality in the taxation of domestic and foreign-source income of U.S. business. Foreign direct investment by U.S. business is neither penalized nor favored by our law in terms of total income tax payable, and the prior right of the foreign countries to tax where income is earned is fully recognized by the allowance of credits for foreign taxes against the U.S. tax.

In practice this seemingly simple and perhaps sensible objective is frequently not achieved because of the interplay of the tax laws of the two or more countries involved in a specific business situation. The fault may lie in the inadequacy of the foreign tax credit, or it may arise because many foreign countries, as well as the United States, impose taxes on both corporate income as it is earned and on dividends paid to foreigners, including dividends paid to foreign parent corporations. The combined burden of the corporate income tax and the withholding tax on dividends may thus exceed the tax on corporate income, which would be the only tax paid by a U.S. corporation on domestic business. Also, different national rules on the allocation of international income between the two or more countries which have a

\footnotetext{
'France is an exception, consolidated financial statements being permitted in certain limited circumstances.
} 
rightful claim to some part of it may lead to a result where the sum of the parts is considerably greater than the whole, in ways which are explained later.

In one way or another, income from foreign direct investment is likely to be subject to a higher income tax burden than that which would be imposed if the business were conducted entirely in one of the two countries. In addition, other forms of taxation, little used in the United States, are imposed at high rates in Europe and are not creditable against the U.S. income tax. Thus the combined total tax burden may be much higher on international business, with income taxes higher in the U.S. and other forms of tax higher in Europe. The repeal of the investment credit, by raising the effective U.S. corporate income tax rate, would increase this general discrepancy.

Neutrality in taxation is frequently cited as one of the principal criteria of an acceptable-one always hesitates to say a "good"-tax system. But neutrality, like equity-another familiar cirterion-has no objective standard against which comparisons can be made. A country may impose all of its own taxes on income from foreign direct investment, subject to credits for foreign taxes, on the theory that this assures neutrality with domestic business and therefore prevents any tax inducement to carry on activities abroad. This is, essentially, the U.S. policy.

Alternatively, a country may recognize that foreign subsidiaries and branches must be able to compete effectively with local business where they operate, and thus should be subject only to the taxes in that country. From this standpoint, neutrality would require exemptions from taxation of income from direct foreign investment in the country of the parent company and full but nondiscriminatory taxation in the country where the business is conducted. This is the policy in the Netherlands, which gives virtual exemption by waiving its own tax if the foreign income has been subject to any income tax, regardless of the rate, in the country where it was earned. Thus, foreign direct investment by companies in the Netherlands can compete on equal tax terms with local competitors wherever they choose to operate, without any overriding tax, current or deferred, in the home country.

Two other standards may be adopted by countries of destination, that is the countries in which the head office or parent companies are located and from which some capital presumably has been exported. The country of destination may impose a low flat rate of tax on income from foreign direct investment, without reference to what taxes, if any, have been imposed by the source country. This is the policy adopted by France, and it was seriously considered in the United States during the middle I950s. It has the advantage of collecting some revenue from business income, a feature which has political appeal and some justification in equity. But if the tax in the source country is as high, or almost as high, as the tax in the country of destination, the combination of two taxes will exceed that which would be applicable 
to domestic business income in either country, thereby discriminating against international investment.

The fourth and final alternative is full taxation of net income from foreign sources in the country of destination. This would be the most onerous of all in imposing heavier burdens on international income. By taxing only net income from foreign sources, the country of destination recognizes the prior right of the country of source to tax but treats that tax as simply another element of cost. With this approach, if each country had a fifty per cent tax, the combined burden would be seventy-five per cent of before-tax income, with the country of source taking fifty per cent of before-tax income and the country of destination taking half of the remainder when paid as a dividend, for the total of seventy-five per cent. The early work in the League of Nations on model tax conventions in the I920s was directed against this simple but restrictive treatment. The system of tax credits developed in the model conventions eliminated the penalty aspect of dual taxation, leaving a burden equal to that of whichever country had the higher tax, assuming no differences arising from definitions or allocations of income.

No major country has failed to take some action to relieve full double taxation of international business income. The tax credit device is probably the most common form of relief. This is sometimes granted unilaterally by statute, as in the United States. In other countries some or all of the credit is granted only in bilateral tax treaties, with the allowance of credits coupled with other important provisions concerning allocation of income, exchange of information, and reciprocal relief provisions waiving taxes on limited categories of income, usually that arising during brief visits by artists, professors, students, or professional specialists. A country which gives a full credit by statute, as the United States has done, has given away an important bargaining position in treaty negotiations.

A review of the points of view underlying the different tax policies with respect to income from foreign direct investment will perhaps help in anticipating the directions of change. Any country may be presumed to be jealous of its right to tax all activities carried on in its borders. It may be expected to be especially sensitive about proposals for special tax treatment of foreign-owned business. Thus, one can start with a presumption that business income will be taxed in the first instance in the country where it is earned. No country disputes this right, though there are different concepts as to the source of income and some reciprocal arrangements have been developed in treaties to waive this right as a matter of public policy or convenience.

The source country may also choose to waive its right to tax on a nonreciprocal basis to encourage both domestic and foreign investment. Tax holidays or special investment allowances are familiar features of economic development programs. Their effectiveness is debatable, as even full tax exemption will not lead to much invest- 
ment in an environment where the prospects for profit are slight or the risks of capital loss are great. But tax concessions are nonetheless often granted in developing countries. When offered, they are typically available in principle to both domestic and foreign investment, though in fact they may be established for particular industries which are carried on almost exclusively by foreign, or by domestic, business.

When a country grants a tax concession to encourage investment, it is understandable that there will be resentment if the revenue which it forgoes is picked up by the country to which the income ultimately goes. This is particularly true when the country foregoing revenue is a "poor" developing country and the country of destination is a "rich" capital-exporting country. This resentment and apparent paradox have been the basis for the many proposals for destination countries to recognize by legislation or treaties the tax concession given where income is earned. It is argued by the countries granting tax concession that the taxes waived should be allowed as credits, along with taxes paid, against the taxes imposed in the countries of destination. Tax sparing has in fact been recognized in various European countries, including the United Kingdom, Sweden, and Germany.

Treaties with clauses recognizing tax sparing were negotiated by the United States in the late I950s but never ratified by the Senate. The Kennedy and Johnson administrations opposed tax sparing and proposed instead an investment credit for investment in developing countries in treaty negotiations. This was never received with particular enthusiasm either in the developing countries or by the Senate. With the probable repeal of the investment credit for domestic purposes, there would be no justification for extending it to foreign investment; in fact, it had little justification even when available for domestic investment because the income from foreign investment was so frequently not subject to any net U.S. tax.

The objections in the developing countries to a failure of destination countries to recognize tax sparing are not altogether well-founded because their own tax concessions are fully effective for foreign subsidiaries until profits are withdrawn from the country. In fact, the existence of a residual U.S. tax on repatriation, which would be reduced or eliminated if tax sparing were recognized, would tend to discourage withdrawal of profits and thereby encourage reinvestment in the developing country, thus reinforcing the basic objective of the tax sparing program. The nullification by the capital-exporting country of the tax concessions of capital-importing countries occurs only when profits are withdrawn from subsidiaries. Current taxation of income of branches does, of course, involve immediate absorption of tax concessions.

The logic regarding recognition of tax sparing has been confused, if not actually mangled, on both sides. One reason given for opposing tax-sparing provisions in treaties was that it encouraged developing countries to give differential tax treatment, and this was stated to be bad in principle. But this objection was, to say the least, incongruous when it was made in an administration which proposed the investment credit for domestic purposes and later proposed extension of it to 
foreign investment in developing countries. Finally, the general increase in taxes abroad to a level such that many, if not most, large companies had excess foreign tax credits meant that U.S. recognition of tax sparing would neither involve significant revenue loss to the United States Treasury nor, correspondingly, significantly increase the net profits of business. At this point, the whole issue would seem to dissolve into unimportance for both countries. But the emotional content is still strong. In capital-importing countries there is resentment about a presumed nullification of the national decision to forgo taxes. And in the capital-exporting countries there is resentment at the idea that "a tax not paid counts as much as a tax which is paid." If this is allowed for income from investment abroad, is there not discrimination against domestic investment? In the absence of more rationality on both sides, it would seem useful to make the virtually costless concession to the emotions prevalent in capital-importing countries, if a tax-sparing clause would help in producing a treaty which is useful in other ways.

The foregoing discussion on tax sparing is relevant primarily to investment in developing countries. Though many countries in Western Europe give tax concession in the form of investment credits or very rapid depreciation allowances, the issue of recognition of a tax-sparing seldom if ever arises in international negotiations with or between them. The arguments concerning it serve, however, to indicate the complexities in analysis and the emotion which develops in international tax affairs.

A more fundamental and pervasive fact is the extent to which the combined burdens of corporate income taxes and withholding taxes on dividends in industrial countries have risen to the point where taxes in the source countries are likely to exceed the taxes due in the countries of destination. In the United States this situation is made more likely by the permission to lump together, in calculating income and credits, the income from all foreign countries and the taxes paid in all foreign countries under the so-called over-all limitation. ${ }^{5}$ This means that a tax at a forty per cent effective rate in one country can be combined with a tax at a sixty per cent effective rate in another country and, with equal amounts of income from each country, the average tax is fifty per cent. If the U.S. tax rate was fifty per cent and the countries were treated separately, an incremental tax of ten per cent would be due on income from the country with the lower rate. But under the over-all limitation the incremental tax is wiped out by the higher tax in the other country. Though the higher tax by itself would not be allowed as a credit against the tax on domestic income, it is allowed as a credit against the incremental tax which would be imposed on other foreign income.

Under a credit sysem it seems reasonable to expect that in the long run the countries where income is earned will find ways to collect taxes at least up to the level allowed as a credit in the countries to which the income will be paid. This can

\footnotetext{
${ }^{6}$ INT. REv. CODE of 1954, $\$ 904(a)(2)$.
} 
readily be accomplished, even if the corporation tax rate is reasonably low, by imposing taxes at fairly high rates on dividends paid to foreign shareholders but with a limitation that the combined tax will not exceed the amount creditable in the destination country. This was, in fact, done in Panama some years ago. It would appear that only inertia prevents similar action elsewhere.

Maximum taxes on dividends are, to be sure, frequently specified in tax treaties, usually at fifteen per cent and sometimes at five per cent on dividends to parent companies. These limitations, however, are more in the nature of conventional figures than calculated amounts designed to assure the destination country that the total foreign taxes will leave room for a residual corporate tax on repatriated profits. Withholding taxes on all dividends are common in Europe as a means of collection. Insofar as they apply to foreign stockholders, the limitations on them do indeed serve to leave room for the country of residence of stockholders to apply a net tax, a result consistent with the general policy that the country of residence should have a reasonable expectation of securing a substantial part of the tax on global income of its residents. (The major exception to this approach exists in Latin America where typically only individual income arising within the country is taxable.)

But insofar as intercorporate dividends are concerned, there is no presumption of a tax in the receiving country. This is implicit in the fact that the underlying corporate tax on income earned by a subsidiary and the withholding tax on the dividend paid to the parent corporation are treated similarly and added together for purposes of determining the credit. ${ }^{6}$

As total creditable foreign taxes come to equal or exceed the United States tax, either directly for individual countries or by operation of the over-all limitation, the whole process of computing the tax which would be due in the absence of the credit and the creditable foreign taxes which offset the U.S. tax becomes a somewhat pointless exercise. It thus seems reasonable on pragmatic grounds to give up the whole attempt to collect revenue when it is clear that little if any will be due. Exemption from taxation of income from direct foreign investment would simply recognize the fact that foreign countries have exercised their admitted first claim to tax income where it arises to such an extent that there is nothing left for us to collect unless we wish to impose what would be, in effect, a penalty tax on foreignsource income.

Tax exemption, however, even if the exemption is from a virtually fictional tax which is seldom if ever payable, may be politically unacceptable. It would be criticized as discriminating in favor of foreign as compared to domestic investment. And in the political arenas, foreign investment is often mistakenly presumed to have adverse effects on the long-run balance of payments, to be at the expense

\footnotetext{
'E.g., INT. REv. CODE of 1954, \$\$ 901-04.
} 
of domestic investment, and to provide jobs abroad at the expense of jobs at home. A more acceptable change in the law might be to establish a rate on income from foreign direct investment at two-thirds or three-quarters the rate applicable to domestic income. This would give effective exemption in virtually all cases by a sufficiently wide margin to obviate the temptation for the home government to attempt to secure revenue from foreign sources by reallocating income and deductions and for foreign governments to raise their taxes selectively to take for themselves any increments of revenue which we would otherwise receive. As compared to outright exemption it would also restrict abuses if foreign income is thrown into tax haven areas where tax rates are nominal.

There is no clear pattern for future development in the taxation of income from direct foreign investment. The effective U.S. corporate tax rate is likely to be higher than those in Western Europe, because of the combination of a high statutory rate and less liberal allowances for depreciation and other inducements for investment. European countries are, therefore, not likely to secure any net revenue from investment by their companies in the United States, unless they follow the French procedure of a low tlat rate of tax with no credit for foreign taxes. Others may choose to follow the Dutch example and give outright exemption. For European investment in Latin America, there may be some small incremental tax due in the countries which follow the U.S. pattern, with credits for foreign taxes. In countries which directly limit the export of capital, neutrality in taxation between foreign and domestic investment is not a major objective since capital export presumably is allowed only when it is deemed to be in the national interest, taking account of both the balance of payments and the allocation of resources.

In the United States there is as yet little disposition to make a major change in our traditional taxation of income from direct foreign investment, though events abroad have made it, as noted, a futile gesture. There is increasing recognition of this fact and of the further fact that in those instances where we do collect an incremental income tax on repatriated profits from foreign subsidiaries, the total income tax burden on them is higher than that on their competitors. The total burden of all taxes is also likely to be higher on foreign subsidiaries of U.S. companies than on domestic business here because of the greater use of value-added and other indirect taxes abroad. But neutrality in the income tax treatment of foreign and domestic investment remains an effective political slogan here, and exemption, though reasonable, is not likely. In fact, suggestions are recurringly made that the United States adopt the French approach, thereby collecting some tax from all foreign investment even though this would violate our traditional objective of neutrality.

There is no consensus as to what, if any, change would be desirable. In view of the development of excess foreign tax credits, the general policy of the U.S. tax treatment cannot be said to be a significant constraint on foreign direct investment. 
Under our tax law, however, we have a tight rule against the use of foreign tax havens which puts U.S. business at a competitive disadvantage because many other industrial countries are quite generous in this regard. U.S. parent corporations are taxed on the undistributed income of their foreign subsidiaries which are deemed to be base or tax haven companies under objective criteria. Prior to Ig62, various devices were developed by which purely domestic profits were "exported" to tax havens, as when U.S. insurance companies reinsured domestic risks with whollyowned subsidiary insurance companies organized in foreign countries which imposed little or no income tax. Some revision of the law was necessary, though many felt that the abuses could have been curtailed by administrative action. The administration recommended, however, that all undistributed income of all foreign subsidiaries be imputed to U.S. parent companies and taxed currently, a procedure never seriously considered in any other country.

The legislation adopted in 1962 , though it stopped short of the proposals of the administration, prevented the use of tax havens even when no profits in any way originating in the United States were involved. If products were manufactured by a subsidiary in country $A$ and sold by a subsidiary in country $B$ through a corporation in country $H$, a tax haven, which received and held most of the profits, it would appear to our national advantage to let the process continue. The use of the tax haven made more net profit ultimately available to the U.S. parent corporation and led to less foreign tax to apply as a credit against U.S. taxes. But under the 1962 legislation, undistributed income of the subsidiary in $H$ is.imputed to and taxed currently to the U.S. parent corporation. The net result is not more U.S. revenue but rather the abandonment of the subsidiary in $H$, with more revenue to foreign countries $A$ and $B$. Net profits are thus reduced, with adverse effects on any revenue which we would otherwise collect. This attempt to extend our tax jurisdiction abroad seems altogether contrary to our national interest. Other countries appear to permit the use of tax havens to increase the competitive effectiveness of their companies internationally. This part of the U.S. tax law represents a futile reaching for revenues with adverse effects on our balance of payments and, in the last analysis, an adverse effect on revenue.

Differences in policies regarding the allocation of international income have already been noted. This is typically an administrative matter and has seldom received attention in general analyses of the tax treatment of international income. It is becoming increasingly important, however, and will be significant regardless of taxability or exemption of foreign income. With exemption, in fact, the burden on the definition of income would become even greater.

Every country has to have some control of the allocation of income between domestic and foreign sources. In the absence of control, all profits on any transaction in any way connected with foreign activity could be allocated to the foreign juris- 
dictions if the taxes there were lower. But the right of the tax administrator to reallocate income gives a great temptation to increase revenues by imputing most of the income to the domestic aspect of an international activity, or even to create income for the domestic component though none exists on the completed transaction. And an overly eager or grasping country may impute to itself a larger fraction of international income than will be recognized by the other countries involved, with a net result that the sum of the segments of income exceed the total income, perhaps by a large margin. Regulations adopted in I968 in the United States under section 482 of the Internal Revenue Code are likely to produce this result. ${ }^{7}$

Under the new regulations, some part of research expenses or the general expenses of the corporate headquarters are likely to be disallowed as deductions against domestic income on the grounds that they are attributable to the activities of foreign subsidiaries. Such a disallowance would not be of great significance if made in good time and if the countries in which the subsidiaries operated would recognize the costs disallowed as expenses here as proper charges to the subsidiaries. But with equally good reasons, the foreign tax administrations might not allow the allocation made here on the grounds that the expenses were primarily for the domestic activities of the U.S. parent company and would have been incurred for it alone. With an impasse of this sort, total taxes may be much larger than those indicated by the statutory tax rate in either country. A company considering activities abroad may run the risk that new foreign profits may be more than wiped out by higher U.S. taxes arising from disallowance of deductions in computing U.S. taxable income, which would otherwise have been unquestioned.

Similar problems arise in determining allowable transfer prices for products between related companies in two or more countries. Exports to subsidiaries may be made at something above marginal costs to yield modest profits in competitive markets abroad. But for tax purposes they may be deemed to be transferred at higher prices based on average or "full" costs, thereby increasing U.S. revenue. But at this presumptive transfer price there would be no profit or even a loss in the foreign country, a result which would be manifestly absurd and unaceptable to the foreign tax administration.

Until recently, most tax administrations handled allocation problems on a fairly pragmatic basis. Gross abuses were penalized, but an ability to compete effectively abroad was recognized as more important than maximum revenue or a theoretically perfect determination of income. The new U.S. regulations have great appeal in theory but fail to recognize the valid interests of other countries and the limitations of tax administrations both here and abroad. The regulations, in fact, invite disallowances of expenses here and will lead to continuing controversy and in many instances to significant tax penalties on international activities of U.S. companies.

\footnotetext{
${ }^{7}$ Treas. Reg. § I.482 (1968).
} 
No major foreign government has a comparable degree of refinement in its procedures for the allocation of income. Over the years, multilateral agreement may and certainly should be reached. In the meantime, however, by unilateral action, the United States has placed its companies at a significant disadvantage. Important though revenue is, it seems unwise to try to increase it at the expense of our even more important balance of payments. 